\title{
Effect of halal food management system certification on buying interest of Indonesian consumer goods
}

\author{
Syafrida Hafni Sahir ${ }^{a *}$, Mochammad Fahlevi ${ }^{b}$ Kasbuntoro $^{c}$ and Sabar Sutiac
}

${ }^{a}$ Fakultas ekonomi dan Bisnis, Universitas Medan Area, Indonesia

${ }^{b}$ Management Department, BINUS Online Learning ,Bina Nusantara University, Indonesia

${ }^{c}$ Kusuma Negara Business School, Indonesia

\section{H R O N I C L E}

\begin{tabular}{l} 
Article history: \\
Received November 20, 2020 \\
Received in revised format \\
January, 28, 2021 \\
Accepted April 102021 \\
Available online \\
April 122021 \\
\hline Keywords: \\
Halal awareness \\
Purchase intention \\
Subjective norms \\
Halal food \\
Theory of planned behavior \\
\end{tabular}

\section{A B S T R A C T}

\begin{abstract}
The purpose of this research is to measure the effect of perceived behavior on purchasing behavior of halal food among consumers in Tangerang which is mediated by purchase intention and moderated by halal awareness. Data collection through online questionnaires was carried out by snowball sampling and the results of questionnaires were returned and valid as many as 300 respondents. Data processing using SEM method with SmartPLS 3.0 software. The results of this study indicate that attitudes, subjective norms and perceptions of behavior control have a significant effect on purchase intention. Meanwhile, purchase intention has a significant effect on the purchasing behavior of working consumers, and halal awareness moderates the effect of purchase intention on purchasing behavior.
\end{abstract}

\section{Introduction}

Indonesia is a country with the most expenditure on halal food, thereby strengthening the potential of the halal culinary market in the country as a lifestyle that is widely accepted by the community. Indonesia is proving that it is not only a halal food market, but also a producer. However, the opportunity as a producer has not been fully utilized. UU no. 33/2014 concerning the Guarantee of Halal Products until now has not had a significant effect on the growth and acceleration of the halal product industry including food and beverages. The number of Muslims in Indonesia and the world continues to increase from time to time, the growth of the middle class increases 7 to 8 percent per year, and the purchasing power increases. This is a very large target market, especially for Indonesia, where the majority of the population is Muslim. More than that, public awareness to consume halal food has also increased. Many of them consider that halal certification is not important, even though this halal certification will encourage the interest of other countries to consume halal food, not only in other countries but also because the food in each city is different. For example, during a study tour to tourist cities in Indonesia, immigrants not only see tours but will look for foods in the city, especially when the tour is Muslim tourism, of course they will look for special foods from the city that are labeled halal or halal certified. This halal-certified food is very important for all of us, besides making it easier for us to find halal-certified food it also makes the Indonesian economy better. Indonesian halal food is still inferior to other countries, for example Japan, South Korea, Thailand, Malaysia. In fact, the greater potential of the halal food market in the world should be able to be utilized properly by the food industry in Indonesia. The development of the halal industry in Indonesia will focus on mapping the constraints that are currently occurring by grouping 5 aspects, namely the first aspect of the policy consisting of the implementation of the Halal Product Guarantee (JPH) which has not been completed, there is still a lack of certification and standardization of halal products, and there is still no roadmap development of the halal industry. Furthermore, the second aspect, namely human resources,

* Corresponding author

E-mail address: agozpor@gmail.com (S. H. Sahir)

(C) 2021 by the authors; licensee Growing Science. doi: 10.5267 j.uscm.2021.4.005 
consists of many producers who do not pay attention to halal products and still lack knowledge of halal products for small business actors. Then, the third aspect of infrastructure is the lack of adequate infrastructure, especially the lack of coordination of the institutions that handle infrastructure. Then, the fourth aspect of socialization consists of a lack of promotion about halal and a lack of socialization, education and information about halal. The fifth aspect of production, namely some constraints such as limited raw materials that meet halal criteria, there are still several sectors that depend on imports and finally there is no standard definition of halal products. An analytical network process (ANP) analysis results show that the main problem in the development of the halal industry is the aspect of human resources and has a good impact on the fast development of the halal industry because it provides a better perception and understanding of the market. Apart from human resources, the next constraints are infrastructure and production. Infrastructure is an obstacle for the development of the halal industry. Infrastructure barriers relate to the implementation of regulations, systems, procedures, and the number of halal guarantee institutions. The next priority is policy and outreach. Furthermore, the formulation of strategies in the development of the halal industry is based on the mapping of obstacles that have been done. This strategy is called the Halal Industry Integration Strategy which has the aim of maximizing the role of every economic actor. These economic players include the government, consumers, investors and industry (Thomson Reuters \& Dinar Standard 2018).

The Halal Industry Integration Strategy includes two things. First, examining factors that can increase the preference of companies or producers in the halal industry to obtain halal certification, which can be driven by demand in the market, especially in Indonesia, where the majority of Muslims tend to think that all products in circulation are halal products. Therefore, checking the halal label on a product to be consumed is not a priority. Second, analyzing the role of each actor in the halal industry. The government as a regulator can maximize in formulating regulations, especially in halal certification, especially in making companies more government to maintain halal certification. Then, consumers by maximizing the urgency of consuming products labeled halal will encourage producers to pay attention to halal guarantees for their products. Then, Islamic financial institutions as investors. Purwanto et al. (2020) explained that industrial collaboration can lead to a harmonious system and can support each other and investors have a role to channel their longterm funds to other halal industries. Lastly, the role of industry. The lack of involvement of Muslims in the industry can reduce the country's image as a country that has great potential to become a major player in the halal industry, especially in the long term. Muslim workers and producers are expected to have a deeper understanding of halal practices, as well as Islamic legal and ethical standards. This can encourage a growing number of products and companies seeking to obtain halal certification.

The halal industry has experienced rapid development in recent years. The halal lifestyle that is synonymous with Muslims has spread to various countries, even to countries with minority Muslim populations. Halal is a universal indicator for product quality assurance and living standards (Gillani et al., 2016; Haro, 2016). Halal is usually only associated with material matters. However, in Islam halal includes deeds and work or commonly referred to as Muamalah (Qardhawi, 1993). Halal can be defined as a quality standard that is in accordance with Islamic Sharia law and is used in every activity carried out by Muslims (Bohari, Cheng, \& Fuad, 2013). Halal products and services are chosen by Muslims as a form of obedience to Islamic Sharia law. Although halal is closely related to Muslims, it does not mean that consumers of halal products only come from Muslims. Consumers of halal products from countries with Muslim minority populations have experienced a significant increase in recent years. The halal industry is experiencing rapid development in several sectors, including: halal food, finance, travel, fashion, cosmetics and medicine, media and entertainment, as well as other sectors such as healthcare and education.

Based on data from the Global Islamic Economy Report for 2016-2017, Indonesia is in the top 10 producers of the halal industry globally. Overall, the world's total expenditure in the halal industry reaches US \$ 2.97 trillion. A total of US \$ 1.9 trillion or equivalent to $\mathrm{Rp} 25,270$ trillion is a contribution from the food sector. Currently, Indonesia is not among the top 10 producers of the halal food industry. The biggest producer of halal food is dominated by Malaysia. According to a researcher in the field of Islamic Economics, optimizing the management of the domestic halal industry can increase the State Budget (APBN). Based on existing data, the halal food industry has a very large market. Based on BPS data, Indonesia has the largest Muslim population in the world. This is a huge economic potential. The halal food industry sector has great potential to be developed. On average, the industrial sector is projected to grow by around eight percent in the period until 2021. It is analogized that if Indonesia can control 10 percent of the potential of the world's halal food industry which reaches IDR 25,270 trillion, it is certain that revenue from the halal food industry will only reach IDR 2,527 trillion. Thus, the increase in sources of state revenue will be even higher (Ali, 2017). The Ministry of Industry has made plans for the establishment of a halal industrial area which is targeted for completion before 2020. This is done in response to the increasing demand for halal products in the world. Halal industrial area is an industrial area in which all industries apply or comply with Islamic standards from upstream to downstream. This Halal Industrial Zone will be selected in the Java region because there is already an industrial area in the consumer goods sector. Meanwhile, for its management, the government will hand over to one of the business actors who already know good halal production standards (http://www.kemenperin.go.id).

The development of the halal market requires increased efficiency in the market to keep pace with this growth. One approach that can be used is supply chain management (SCM) (Noordin et al., 2014). SCM can be used to increase the productivity 
and profitability of the halal market (Noordin et al, 2014). Strategic and systemic coordination of business functions in a company is the key to the successful implementation of SCM in the company. Traditional SCM can be defined as the process of converting raw materials into finished goods for further distribution to the end consumer (Manzouri, AbRahman, Zain, \& Jamsari, 2014). In the increasingly rapid development of the industry, especially the development of the halal industry, traditional SCM is deemed insufficient to accommodate market needs. Therefore, SCM develops according to industry needs to become a halal supply chain. Halal supply chain can be defined as the integration of business processes and activities from raw materials to end consumers (from farm to plate) (Omar \& Jaafar, 6 Faqiatul MW \& Anissa HP, Halal Food Industry Development Model in Indonesia 2011). So, the difference between SCM and halal supply chain is the goal. Supply chain management (SCM) is implemented in companies so that companies can reduce production costs. On the other hand, the halal supply chain is used by companies with the aim of maintaining and maintaining the halalness of the product (Gillani et al, 2016; Azam, 2016). The maintained halal integrity of the product will be one of the competitive advantages for producers to be able to compete with other producers in the same industry. The following is an example of a halal supply chain image to be able to maintain a halal product. Only halal species are allowed to be bred and these halal species do not consume prohibited food.

The purpose of this study is to prove that attitudes influence the buying interest in halal products, analyze and find out whether or not attitudes have a positive effect on buying interest in halal products, analyze and find out whether subjective norms have a positive effect on buying interest in halal products, analyze and find out whether or not perceptions of behavior control have a positive effect on buying interest in halal products, analyze and find out whether or not purchase intention has a positive effect on buying behavior of halal products, analyze and find out whether halal awareness moderates positive influence of interest in buying behavior of halal food products.

\section{Method}

Referring to previous theory and research, there is a relationship between variables which includes attitudes, subjective norms and perceptions of behavioral control, purchase intention, halal awareness and purchasing behavior. The author builds a research model as follows:

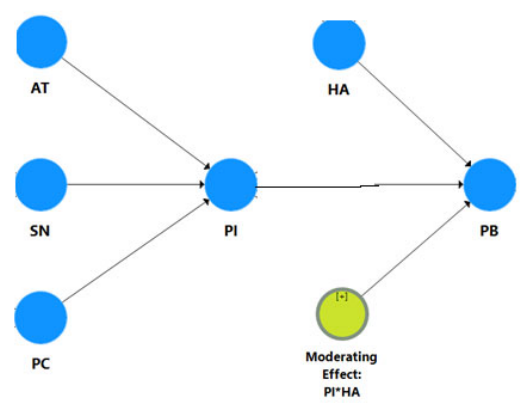

Fig. 1. Research Model

The above research results prove that attitudes have an effect on buying interest in halal products. Based on the description above, the hypotheses of this research are as follows:

$\mathrm{H}_{1}$ : Attitudes have a positive effect on buying interest in halal products.

$\mathrm{H}_{2}$ : Subjective norms have a positive effect on buying interest in halal products.

$\mathrm{H}_{3}$ : Perception of behavior control has a positive effect on buying interest in halal products.

$\mathrm{H}_{4}$ : Purchasing intention has a positive effect on the buying behavior of halal products.

$\mathrm{H}_{5}$ : Halal awareness moderates the positive influence of interest in buying behavior of halal food products.

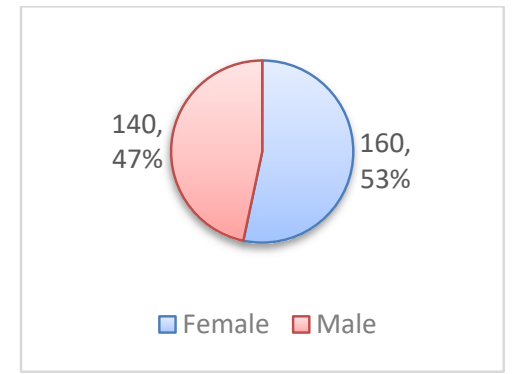

Gender
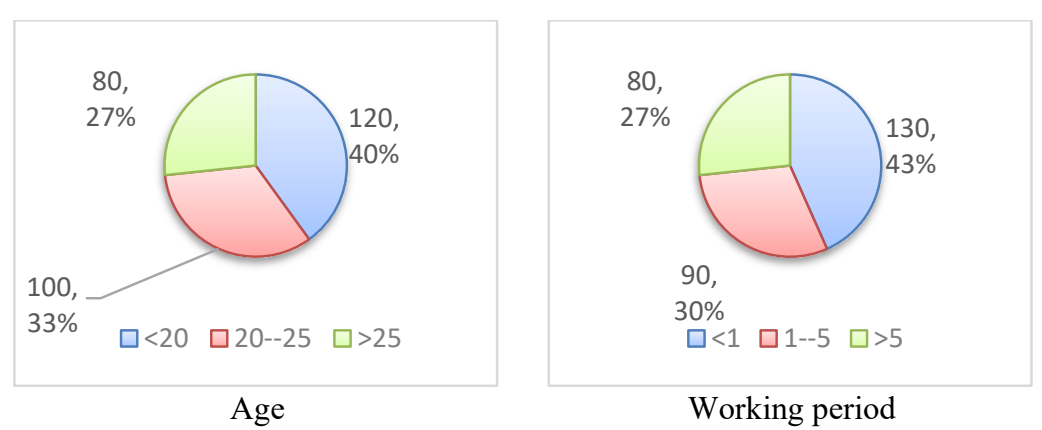

Fig. 2. Personal characteristics of the participants 
The method used in this research is quantitative method. Data collection was carried out by distributing questionnaires to 300 halal food consumers. The questionnaire was designed closed except for questions / statements regarding the identity of the respondents in the form of a semi-open questionnaire. Each closed question / statement item is given five answer choices, namely: strongly agree (SS) score 5, agree score (S) 4, neutral score (N) 3, disagree score (TS) 2, and strongly disagree score (STS ) 1. The data processing method uses PLS and uses SmartPLS version 3.0 software as a tool. The respondents in this study were 300 working consumers at one of the private universities in Tangerang, Indonesia. The questionnaires were distributed using simple random sampling technique.

\section{Result and Discussion}

\subsection{Validity and Reliability Test}

The testing phase of the measurement model includes testing for convergent, validity discriminant validity. Meanwhile, to test construct reliability, Cronbach's alpha value and composite reliability were used. The results of the PLS analysis can be used to test the research hypothesis if all indicators in the PLS model have been implemented to meet the requirements of convergent validity, discriminant validity and reliability test and validity tests are carried out by looking at thevalue loading factor of each indicator against the construct. In most references, a factor weight of 0.5 or more is considered to have sufficiently strong validation to explain latent constructs (Chin, 1998; Ghozali, 2014; Hair et al., 2010). In this study, the minimum limit for loading factor the accepted is 0.5, provided that the AVE value of each construct is $>0.5$ (Ghozali, 2014). Based on the results of SmartPLS 3.0 processing, all indicators have a value loading factor above 0.5. So thus, the convergent validity of this research model has met the requirements. The value of loadings, cronbach's alpha, composite reliability and AVE for each complete construct can be seen in Table 1 below:

Table 1

Items Loadings, Cronbach's Alpha, Composite Reliability, and Average Variance Extracted (AVE)

\begin{tabular}{|c|c|c|c|c|c|}
\hline Variables & Items & Loadings & Cronbach's Alpha & Composite Reliability & AVE \\
\hline \multirow{5}{*}{$\begin{array}{l}\text { Attitude } \\
\text { (AT) }\end{array}$} & AT1 & 0.976 & \multirow[t]{5}{*}{0.912} & \multirow[t]{5}{*}{0.912} & \multirow[t]{5}{*}{0.778} \\
\hline & AT2 & 0.923 & & & \\
\hline & AT3 & 0.824 & & & \\
\hline & AT4 & 0.857 & & & \\
\hline & AT5 & 0.824 & & & \\
\hline \multirow{5}{*}{$\begin{array}{l}\text { Subjective Norm } \\
\text { (SN) }\end{array}$} & SN1 & 0.979 & \multirow[t]{5}{*}{0.989} & \multirow[t]{5}{*}{0.913} & \multirow[t]{5}{*}{0.731} \\
\hline & $\mathrm{SN} 2$ & 0.998 & & & \\
\hline & SN3 & 0.978 & & & \\
\hline & SN4 & 0.867 & & & \\
\hline & SN5 & 0.867 & & & \\
\hline \multirow{4}{*}{$\begin{array}{l}\text { Perceived Control } \\
(P C)\end{array}$} & PC1 & 0.867 & \multirow[t]{4}{*}{0.900} & \multirow[t]{4}{*}{0.931} & \multirow[t]{4}{*}{0.723} \\
\hline & PC2 & 0.863 & & & \\
\hline & PC3 & 0.976 & & & \\
\hline & PC4 & 0.843 & & & \\
\hline \multirow{5}{*}{$\begin{array}{l}\text { Purchase Intention } \\
\text { (PI) }\end{array}$} & PI1 & 0.765 & \multirow[t]{5}{*}{0.903} & \multirow[t]{5}{*}{0.932} & \multirow[t]{5}{*}{0.721} \\
\hline & PI2 & 0.712 & & & \\
\hline & PI3 & 0.942 & & & \\
\hline & PI4 & 0.812 & & & \\
\hline & PI5 & 0.815 & & & \\
\hline \multirow{3}{*}{$\begin{array}{l}\text { Halal Awareness } \\
\text { (HA) }\end{array}$} & HA1 & 0.815 & \multirow[t]{3}{*}{0.821} & \multirow[t]{3}{*}{0.893} & \multirow[t]{3}{*}{0.712} \\
\hline & HA2 & 0.836 & & & \\
\hline & HA3 & 0.836 & & & \\
\hline \multirow{3}{*}{$\begin{array}{l}\text { Purchase Behavior } \\
\text { (PB) }\end{array}$} & PB1 & 0.876 & \multirow[t]{3}{*}{0.942} & \multirow[t]{3}{*}{0.912} & \multirow[t]{3}{*}{0.814} \\
\hline & PB2 & 0.972 & & & \\
\hline & PB3 & 0.987 & & & \\
\hline
\end{tabular}

Discriminant validity is carried out to ensure that each concept of each latent variable is different from other latent variables. The model has good discriminant validity if the AVE square value of each exogenous construct (the value on the diagonal) exceeds the correlation between this construct and other constructs (values below the diagonal) (Ghozali, 2014). The results of testing discriminant validity using the AVE square value, namely by looking at the Fornell-Larcker Criterion Value (Fornell \& Larcker, 1981b), were obtained as follows:

Table 2

Discriminant Validity

\begin{tabular}{|c|c|c|c|c|c|c|c|}
\hline Variables & AT & HA & PI $\times$ HA & PB & PC & PI & $\mathbf{S N}$ \\
\hline Attitude & 0.832 & & & & & & \\
\hline Halal Awareness & 0.624 & 0.813 & & & & & \\
\hline Moderating Effect: PI*HA & 0.134 & 0.113 & 1.000 & & & & \\
\hline Purchase Behavior & 0.776 & 0.665 & 0.164 & 0.965 & & & \\
\hline Perceived Control & 0.723 & 0.789 & 0.212 & 0.816 & 0.813 & & \\
\hline Purchase Intention & 0.867 & 0.632 & 0.013 & 0.813 & 0.878 & 0.878 & \\
\hline Subjective Norm & 0.864 & 0.621 & 0.213 & 0.713 & 0.713 & 0.813 & 0.898 \\
\hline
\end{tabular}


Table 3

Collinearity Statistics (VIF)

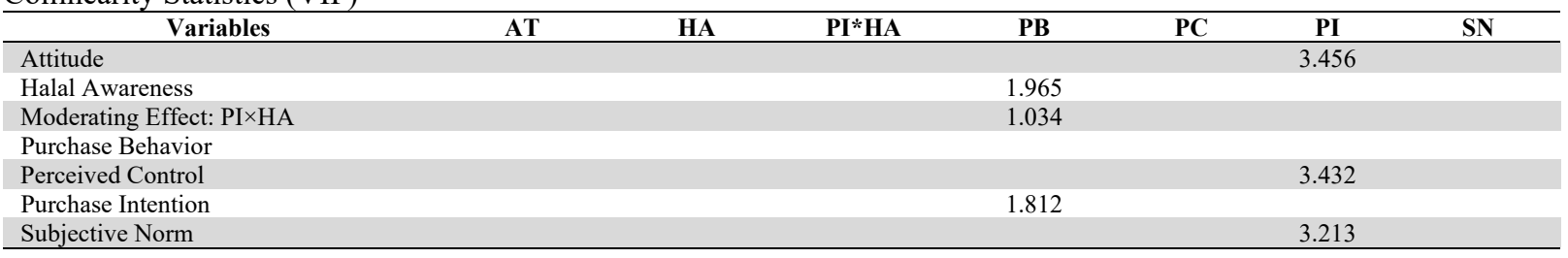

The results of the discriminant validity test in Table 3 above show that all constructs have a square root value of AVE above the correlation value with other latent constructs (through the Fornell-Larcker criteria). Likewise, the cross-loading value of all items from an indicator is greater than the other indicator items as mentioned in Table 4, so it can be concluded that the model has met the discriminant validity (Fornell \& Larcker, 1981a). Furthermore, a collinearity evaluation is carried out to determine whether there is collinearity in the model. To find collinearity, it is necessary to calculate the VIF of each construct. If the VIF score is higher than 5, then the model has collinearity (Hair et al., 2014). As shown in Table 4, all VIF scores are less than 5, meaning that this model has no collinearity. Construct reliability can be assessed from the Cronbach's alpha value and the composite reliability of each construct. The recommended values, composite reliability and Cronbach alpha are more than 0.7 (Ghozali, 2014). The reliability test results in Table 1 above show that all constructs have values of composite reliability and Cronbach alpha greater than $0.7(>0.7)$. In conclusion, all constructs have met the required reliability.

\subsection{Hypothesis Testing}

Hypothesis testing in PLS is also called the inner model test. This test includes a significance test for direct and indirect effects as well as measuring the magnitude of the influence of exogenous variables on endogenous variables. The effect test was performed using the t-statistic test in the analysis model partial least square (PLS) using the software SmartPLS 3.0. With the technique bootstrapping, the values for $R$ Square andsignificance test values as shown in the table below:

Table 4

$\underline{\text { R Square Value }}$

\begin{tabular}{lll}
\hline & R Square & R Square Adjusted \\
\hline Purchase Behavior (PB) & 0.811 & 0.773 \\
Purchase Intention (PI) & 0.733 & 0.712 \\
\hline
\end{tabular}

Table 5

Hypothesis Testing

\begin{tabular}{llccccc}
\hline Hypotheses & Relationship & Beta & SE & T Statistics & P-Values & 0.000 \\
H1 & AT $\rightarrow$ PI & 0.321 & 0.023 & 4.630 & Decision & Supported \\
H2 & SN $\rightarrow$ PI & 0.221 & 0.023 & 3.478 & Supported & Supported \\
H3 & PC $\rightarrow$ PI & 0.332 & 0.057 & 3.857 & 0.000 & 0.000 \\
H4 & PI $\rightarrow$ PB & 0.778 & 0.067 & 15.436 & Supported & Supported \\
H5 & PI $\times$ HA $\rightarrow$ PB & 0.089 & 0.046 & 2.114 & 0.023 \\
\hline
\end{tabular}

Based on Table 5 above, the value of $R$ SquarePurchase intention (PI) is 0.811 , which means that the variable purchase intention (PI) can be explained by the variable attitude $(A T)$, subjective norm (SN) and perceived control (PI) of $81.1 \%$, while the remaining $18.9 \%$ is explained by other variables not discussed in this study. Value of $R$ SquarePurchase behavior (PB) is 0.733 which means that the purchase behavior (PB) variable can be explained by the variable purchase intention (PI) and halal awareness (HA). $73.3 \%$, while the remaining $26.7 \%$ is explained by other variables not discussed in this study. Meanwhile, Table 6 shows the $T$ Statistics and P-Values which show the influence between the research variables that have been mentioned.

\subsection{The Effect of Attitudes on Purchase Intention for Halal Food Products}

Purchase intentions of consumers come from consumer attitudes and assessments of a product as well as external factors of the product. Attitudes, judgments, and other external factors are very important factors in predicting consumer behavior. Purchase intention can measure how likely consumers are to buy a product, where the higher the purchase intention the higher the consumer's intention to buy the product. The results of the study (Abd-Rahman et al., 2015) prove that attitudes have a positive effect on intention use of halal products (Abd-Rahman et al., 2015; Alserhan, 2015). Research using Theory of Reasoned Action (TRA) found that attitudes are positively related to the intention to choose halal products among consumers (Mukhtar \& Butt, 2012). 
The results of this study prove that subjective norms have a positive effect on buying interest in halal food products. The higher the influence of the reference group on halal food, the higher the interest in purchasing halal food. A predictor of social factors called subjective norms is the social pressure that is felt to meet expectations about involvement in a behavior that must influence the individual's intention to do or not to do that behavior. If the social expectation is that people should perform in the behavior in question, then individuals should be more inclined to do so. Conversely, if the social expectation is that one should not perform in a behavior, then the individual should be inclined to do so. In this case, if the purchase of halal food is seen as socially desirable behavior, based on what other important people think about it, then individuals are more likely to purchase halal food. In this study, subjective norms are perceived social pressures that influence consumer decisions to buy halal food (Alam \& Sayuti, 2011). The research results of Bashir, Bayat, Olutuase, \& Abdul Latiff (2019), Alam \& Sayuti, (2011), and Afendi, Azizan, \& Darami (2014) prove that subjective norms have an effect on buying interest in halal products.

\subsection{The Effect of Perception of Behavioral Control on Purchase Intention for Halal Food Products}

The results of this study prove that Perceptions of Behavior Control have a positive effect on buying interest in halal food products. The higher the Perception of Behavioral Control towards halal food, the higher the interest in purchasing halal food. Perceived behavioral control is the extent to which a person feels capable of engaging in the behavior. This has two aspects: how much control a person has over the behavior and how confident one is about being able to or not perform the behavior. It is determined by the individual's belief about the power of both situational and internal factors to facilitate the performance of the behavior. The more control a person feels about making a halal food purchase, the more likely he or she will. In this study, perceived behavioral control is the ability to buy halal food (Afendi et al., 2014). The results of research by Bashir et al. (2019), Alam and Sayuti (2011), and Afendi et al. (2014) prove that perceptions of behavior control have an effect on buying interest in halal products

\subsection{The Influence of Purchase Intention for Halal Food Products on Purchasing Behavior of Halal Food Products}

The results of this study prove that buying interest has a positive effect on purchasing behavior towards halal food products. The higher the buying interest in halal food will increase the buying behavior of halal food. Purchase interest reflects the short-term behavior of consumers in the future for future purchasing decisions (next shopping plan). Purchase interest is the most appropriate thing to predict consumer behavior. Purchase intention refers to the possibility of consumers buying a product. Purchase intention is an individual's conscious plan to make an effort to buy a product (Listyoningrum \& Albari, 2012). Purchasing interest refers to an individual's readiness and willingness to buy a particular product or service (Ajzen, 1991, 2005a, 2005b, 2005c, 2020), and it can influence consumer purchasing decisions in the future. This can be considered as one of the cognitive behavioral mechanisms of consumers on how consumers intend to buy certain products (Bashir et al., 2019). Intention can be a reliable predictor of behavior. Purchasing behavior comes from adequate awareness of the product (Bashir et al., 2019).

\subsection{The Effect of Halal Awareness in Moderating the Relationship between Purchasing Interest in Halal Food Products on Purchasing Behavior of Halal Food Products}

The awareness of Muslims in Indonesia tends to increase accompanied by MUI data where the products registered for obtaining a halal certificate have also increased. Consumers begin to look for what is good and useful for themselves to consume. When people begin to realize that consuming halal food is important for themselves, this will have a positive impact on the interest in buying halal products. The greater the level of understanding of a Muslim towards halal, the more positive a Muslim's behavior will be regarding issues related to halal. This also affects the buying interest of Muslims to consume products in accordance with Islamic rules. Therefore, halal awareness increases the positive influence of attitudes on the interest in buying halal food products. The research results of Nurhasanah and Hariyani (2018) and Bashir et al. (2019) prove that halal awareness increases buying interest and purchasing behavior of halal products. Others state that halal certification has a positive effect on buying interest. This contradicts the research conducted by Nurhasanah and Hariyani (2018), which states that halal certification has no significant effect on purchase intention. Manufacturers in selling their products need a marketing strategy so that consumers know the products offered and attract their buying interest in the products being sold. A study conducted by Awan et al. (2015) states that halal marketing has a positive effect on buying interest. This contradicts the research conducted by Suhartanto et al. (2019) and Putri and Rimadias (2019), where the results of this study show that halal marketing does not have a positive effect on buying interest. Awan, et al (2015) in their research show that religiosity and personal social perceptions have a positive effect on Muslim consumer buying interest. Based on the differences in the results of these studies, it is necessary to conduct more in-depth research on the factors that can affect Muslim consumer buying interest in halal food. The halal awareness variable has a positive and significant effect on buying interest in halal products. This shows that if someone has better halal awareness, it will increase the person's intention to buy halal products (Putri \& Rimadias, 2019). The halal certification variable has a positive and significant effect on buying interest in halal bread products. This shows that halal certification has a positive influence on respondents' interest 
in buying Halal food because halal certification provides a guarantee of product quality. Factors Affecting Intention to Buy Halal food to consumers when they express their desire to purchase halal products in the future (Aziz \& Chok, 2013). The religiosity variable has a positive and significant effect on Muslim consumer buying interest for halal bread products. This is because when a Muslim is obliged to eat halal food and to prevent himself from consuming what is haram, it is a form of obedience to religion. So that when someone's level of faith gets higher, it will increase the person's interest in buying Halal food. On the other hand, if a person's faith level gets lower, the lower the person's interest in buying halal bread. Halal marketing variables have a positive and significant effect on Muslim consumer buying interest for Halal food products. This proves that the effect of halal marketing carried out by producers such as promotions, advertisements, brands and prices affect consumers' buying interest in Halal food products. Marketing and promotion related to halal food products is able to direct consumers to halal awareness because designs related to halal awareness are one of all marketing objectives and also Muslim consumers still consider their religion in consuming halal food (Fitria, Hermawan, \& Asnawi, 2019) Personal social perception variables have a positive and significant effect on Muslim consumer buying interest in Halal food products. Purchase interest of a consumer can arise due to pressure, both social and personal. This is due to the influence of themselves and the social environment of consumers such as the work environment, friendship, family and have an impact on the control of consumers' personal behavior on the interest in buying halal food products (Awan et al., 2015).

\section{Conclusion}

Based on the results of the study, it is concluded that the attitude, subjective norms and perceptions of behavior control have a positive effect on buying interest in halal food products. Purchasing intention has a positive effect on the buying behavior of halal food and in this study proves that halal awareness is able to moderate the effect of purchase intention on purchasing behavior of halal food products. The higher the awareness of halal will increase the relationship between buying interest and buying behavior of halal food. The results of this study also show that it is important to pay attention to halal awareness in the form of increasing the relationship between buying interest and buying behavior of halal food products so that halal food producers must be able to increase the perception of halal awareness of every consumer.

\section{References}

Abd-Rahman, A., Asrarhaghighi, E., \& Ab-Rahman, S. (2015). Consumers and Halal cosmetic products: knowledge, religiosity, attitude and intention. Journal of Islamic Marketing, 6(1), 148-163. https://doi.org/10.1108/JIMA-09-20130068

Afendi, N. A., Azizan, F. L., \& Darami, A. I. (2014). Determinants of halal purchase intention: case in Perlis. International Journal of Business and Social Research, 4(5), 118-123.

Alam, S. S., \& Sayuti, N. M. (2011). Applying the Theory of Planned Behavior (TPB) in halal food purchasing. International journal of Commerce and Management, 21(1).

Ajzen, I. (1991). The Theory of Planned Behavior. Organizational Behavior and Human Decision Processes, 50, $179-211$. https://doi.org/https://doi.org/10.1016/0749-5978(91)90020-T

Ajzen, I. (2015a). Consumer attitudes and behavior: the theory of planned behavior applied to food consumption decisions. Consumer Attitudes and Behavior: The Theory of Planned Behavior Applied to Food Consumption Decisions, 70(2), 121-138. https://doi.org/10.13128/REA-18003

Ajzen, I. (2015b). Consumer attitudes and behavior: the theory of planned behavior applied to food consumption decisions. Italian Review of Agricultural Economics, 70(2), 121-138.

Ajzen, I. (2015c). The theory of planned behaviour is alive and well, and not ready to retire: a commentary on Sniehotta, Presseau, and Araújo-Soares. Health Psychology Review, 9(2), 131-137.

Ajzen, I. (2020). The theory of planned behavior: Frequently asked questions. Human Behavior and Emerging Technologies, 2(4), 314-324.

Ali, A., Xiaoling, G., Sherwani, M., \& Ali, A. (2017). Factors affecting Halal meat purchase intention. British Food Journal. Alserhan, B. A. (2015). The principles of Islamic marketing. Ashgate Publishing, Ltd.

Azam, A. (2016). An empirical study on non-Muslim's packaged halal food manufacturers: Saudi Arabian consumers' purchase intention. Journal of Islamic Marketing, 7(4), 441-460. https://doi.org/10.1108/JIMA-12-2014-0084

Aziz, Y. A., \& Chok, N. V. (2013). The Role of Halal Awareness, Halal Certification, and Marketing Components in Determining Halal Purchase Intention Among Non-Muslims in Malaysia : A Structural Equation Modeling Approach. Journal of International Food \& Agribusiness Marketing, 25(1), 1-23. https://doi.org/10.1080/08974438.2013.723997

Awan, H. M., Siddiquei, A. N., \& Haider, Z. (2015). Factors affecting Halal purchase intention-evidence from Pakistan's Halal food sector. Management Research Review, 38(6).

Bashir, A. M., Bayat, A., Olutuase, S. O., \& Abdul Latiff, Z. A. (2019). Factors affecting consumers' intention towards purchasing halal food in South Africa: a structural equation modelling. Journal of Food Products Marketing, 25(1), 2648. https://doi.org/10.1080/10454446.2018.1452813

Bohari, A. M., Hin, C. W., \& Fuad, N. (2013). The competitiveness of halal food industry in Malaysia: A SWOT-ICT analysis Malaysia. Journal of Society and Space, 9(1), 1-9.

Chin, W. (1998). The Partial Least Squares Approach to Structural Equation Modeling (E. Modern Methods for Business Research, In: G. A. Marcoulides (ed.)). Lawrence Erlbaum Associates Publisher. 
Fornell, C., \& Larcker, D. F. (1981a). Evaluating Structural Equation Models with Unobservable Variables and Measurement Error. Journal of Marketing Research, 18(1), 39. https://doi.org/10.2307/3151312

Fornell, C., \& Larcker, D. F. (1981b). Evaluating Structural Equation Models with Unobservable Variables and Measurement Error. Journal of Marketing Research, 18(1), 39-50. https://doi.org/10.1177/002224378101800104

Gillani, S., Ijaz, F., \& Khan, M. M. S. (2016). Role of islamic financial institutions in promotion of Pakistan halal food industry. Islamic Banking and Finance Review, 3(01), 29-49.

Hair, J. F., Black, W. C., Babin, B. J., \& Anderson, R. E. (2010). Multivariate Data Analysis (7th ed.). Pearson Prentice Hall.

Hair, J. F., Hult, G. T., Ringle, C. M., \& Sarstedt, M. (2014). A primer partial least squaresstructural equation modeling (PLS-SEM). SAGE Publications.

Haro, A. (2016). Understanding TPB model, availability, and information on consumer purchase intention for halal food. International Journal of Business and Commerce, 5(8), 47-56.

Manzouri, M., Ab-Rahman, M. N., Zain, C. R. C. M., \& Jamsari, E. A. (2014). Increasing production and eliminating waste through lean tools and techniques for halal food companies. Sustainability, 6(12), 9179-9204.

Mukhtar, A., \& Butt, M. M. (2012). Intention to choose Halal products: the role of religiosity. Journal of Islamic Marketing.

Noordin, N., Noor, N. L. M., \& Samicho, Z. (2014). Strategic approach to halal certification system: An ecosystem perspective. Procedia-Social and Behavioral Sciences, 121, 79-95.

Nurhasanah, S., \& Hariyani, H. F. (2018). Halal Purchase Intention on Processed Food. Tazkia Islamic Finance and Business Review, 11(2).

Purwanto, H., Fauzi, . M., Wijayanti, . R., Awwaly, . K. U. A., Jayanto, . I., Mahyuddin, ., Purwanto, . A., Fahlevi, . M., Adinugraha, H. H., Syamsudin, . R. A., Pratama, . A., Ariyanto, . N., Sunarsi, . D., Hartuti, . E. T. K. \& Jasmani, . (2020) Developing Model of Halal Food Purchase Intention among Indonesian Non-Muslim Consumers: An Explanatory Sequential Mixed Methods Research. Systematic Reviews in Pharmacy, 11 (10), 396-407. doi:10.31838/srp.2020.10.63 Qardhawi, Y. (1993). Halal dan Haram dalam Islam, terj. Mu'amal Hamidy, Jakarta: Bina Ilmu.

Putri, M. J., \& Rimadias, S. (2019). Analisis aspek penentu niat konsumen dalam membeli produk halal di indonesia (telaah pada mie ramen jepang halal). Prosiding Seminar Akuntansi Nasional, 2(1).

Suhartanto, D., Marwansyah, M., Muflih, M., Najib, M. F., \& Faturohman, I. (2019). Loyalty formation toward Halal food: integrating the quality-loyalty model and the religiosity-loyalty model. British Food Journal, 122(1), 48-59.

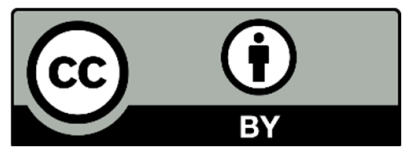

(C) 2021 by the authors; licensee Growing Science, Canada. This is an open access article distributed under the terms and conditions of the Creative Commons Attribution (CC-BY) license (http://creativecommons.org/licenses/by/4.0/). 